Bull. Fac. Agric., Cairo Univ., 67: 315-326(2016).

\title{
PREDICTION OF THE QUALITY CHARACTERISTICS OF GLUTEN-FREE CORN MUFFINS AS AFFECTED BY THE ADDITION OF SOYBEAN FLOUR AND XANTHAN GUM.
}

(Received: 5.12.2016)

\author{
By \\ M.H. Abd-El-Khalek, A. M. Sakr and M.H. Abd El-Kader \\ Food Technology Research Institute, Agricultural Research Center, Giza, Cairo, Egypt.
}

\begin{abstract}
The present study aimed to investigate the effect of using soybean flour to replace up to $40 \%$ of corn flour along with different concentrations of xanthan gum for the production of gluten-free corn muffins. The results showed that the produced muffins had higher contents of protein, dietary fiber and ash, with less carbohydrate the content. Physical properties of muffins containing soybean flour and xanthan gum were comparable to control muffins. With regard to overall sensory acceptability, replacement of corn flour up to $20 \%$ with the same amount of soybean flour in the presence of $1 \mathrm{~g}$ xanthan gum resulted in muffins that were not significantly different than control ones. When prediction equations for the effects of using soybean flour and xanthan gum were derived, it was found that all chemical constituents were changed with equations of first (linear) order of process. Moreover, the prediction equations of the physical properties varied from linear to cubic order. The prediction equations of the sensory characteristics varied from linear to quadratic with reasonable to high values for $\mathrm{R}^{2}$ and adequate precision. The optimized muffin formula for the achievement of very much like target was found to contain $11.05 \%$ and $0.99 \mathrm{~g}$ of soybean flour and xanthan gum, respectively.
\end{abstract}

Key words: Gluten-free, corn muffins, soybean flour, xanthan gum, quality, prediction.

\section{INTRODUCTION}

Celiac disease (CD) is an immune-mediated enteropathy triggered by the ingestion of gluten in genetically susceptible individuals. Gluten is the main protein component in wheat, rye and barley (Cureton and Fasano, 2009). Recent epidemiological studies show that the prevalence of celiac disease is underestimated among the population of Mediterranean regions such as the Middle East and North Africa (Cataldo and Montalto, 2007 and Barada et al., 2010). In Egypt, the number of celiacs (estimated at minimum rate of $1 \%$ of population) is expected to exceed 800,000 persons. Anaemia, osteopenia and short stature (in children) are three of the clinical complaints associated with the $\mathrm{CD}$ epidemic (Greco et al., 2011). At present, the only available treatment for CD is a strict gluten-free diet. Thus, food manufacturers have also responded to the increased need for gluten-free foods (Cureton and Fasano, 2009).
Baking is a millennia old process, and bakery products have a wide and complex range from single ingredients of plain pastry to the numerous components of a cake. Wheat flour is the most important ingredient as it provides bulk and structure to the most bakery products (Lai and Lin, 2006). The gluten of wheat has the unique ability to retain gas produced by either fermentation or by chemical leavening agents which result in a leavened product (Hoseney, 1989), the use of gluten-free cereal flours is of a big challenge.

Corn (Zea mays) flour is one of the alternatives that can be safely used in place of wheat flour in the celiac diet (Preichardt et al., 2011). As a result of not containing any gluten, corn flour based dough does not demonstrate rheological properties comparable to those of a wheat flour based dough (Renzetti et al., 2008).

Soybean flour is gaining popularity among bakers as consumers request products containing health benefits found in soy (Backman, 2008). The 
advantages and health benefits of using soy flour includes: increasing the quantity and the quality of protein in some foods, lowering blood cholesterol ,reducing the risk of heart disease, potential to fight osteoporosis and acting as an anticarcinogenic agent. (Riaz, 1999, Venter, 1999, Sadler, 2005 and Backman, 2008).

Starchy flours can be enhanced by mixing them with hydrocolloids to achieve certain functionality in a gluten-free food system, that is, the formation of cohesive and elastic dough or stabilization of air cells (Abdel-Aal, 2009). Xanthan gum is a hetero polysaccharide with a primary structure consisting of repeated pentasaccharide units formed by two glucose units, two mannose units, and one glucuronic acid unit in the molar ratio 2.8:2.0:2.0. Its main chain consists of B-D-glucose units linked at the 1 and 4 positions (García-Ochoa et al., 2000 and Köksel, 2009). Incorporation of xanthan gum into glutenfree bakery products can add some advantageous rheological properties. Xanthan gum helps in retention of $\mathrm{CO}_{2}$ gas that consequently leads to an increase in specific volume of the products (Gómez et al., 2007 and Tubari et al., 2008). Moreover, gluten-free cakes prepared with xanthan gum were found to have a firmer structure and did not collapse in the oven (Tubari et al., 2008).

The present study aimed to investigate the effects of replacing portions (up to 40\%) of corn flour by soybean flour with the addition of xanthan gum at levels up to $1 \%$ (flour weight basis) on the nutritional, physical and sensory quality characteristics of gluten-free corn muffins. Deriving predictive equations for the responses of such effects were also carried out on the resulted data.

\subsection{Materials}

\section{MATERIALS AND METHODS}

Raw materials used in muffin preparation (i.e., yellow corn flour, fresh eggs, margarine, sugar, vanilla, salt and baking powder) were purchased from a local market in Cairo, Egypt. Low-fat soybean flour was obtained from Soybean Processing Plant at the Food Technology Research Institute (FTRI), Agricultural Research Center, Giza, Egypt. Xanthan gum was provided by Misr Food Additives (MIFAD), Badr City, Egypt.

\subsection{Methods}

\subsubsection{Preparation of gluten-free muffins}

The formulations of gluten-free corn muffins with or without soybean flour (by replacing 10, 20, 30 and $40 \%$ of corn flour weight) and xanthan gum (by addition levels of $0.3,0.6$, and $1 \mathrm{~g}$ ) are shown in Table (1). Muffins were prepared using the method followed at the Corn products research unit in Food Technology Research Institute (FTRI) as follows:

Hot water was mixed with corn flour and the mixture was let for $15 \mathrm{~min}$. Eggs, cold water, sugar, margarine and salt were added to corn flour batter and were well beaten using a Moulinex mixer (Supermix 150). After beating, baking powder was added to the above mixture and well stirred. An amount of batter (25 g) was weighed and placed in greased paper baking cups in an aluminum muffin pan (cup size $7.6 \times 3.2 \mathrm{~cm}$, bottom diameter $5.2 \mathrm{~cm}$ ). The muffins were baked in an oven at $190^{\circ} \mathrm{c}$ for $20 \mathrm{~min}$. After baking, muffins were removed from pans, allowed to cool for $1 \mathrm{hr}$, then the baking papers were removed and muffins were kept for further examinations.

\subsubsection{Chemical composition analysis}

Muffins were analyzed for their contents of moisture, protein, dietary fiber, fat (as ether extract) and ash using the methods outlined in A.A.C.C. (2000). Digestible carbohydrates were calculated by difference.

\subsubsection{Physical properties}

Density of the batter was measured by dividing the weight of the batter in a filled container by the volume of the same container. Four muffins from each formulation were subjected to the following physical measurements:

Muffin height was measured with a caliper from the highest point of the muffin to its bottom (Martínez-Cervera et al., 2011). Volume of the muffins (in $\mathrm{cm}^{3}$ ) was determined by rapeseed displacement (AACC, 2000). Specific volume was calculated by dividing the volume of muffins $\left(\mathrm{cm}^{3}\right)$ by their weight $(\mathrm{g})$ as described by Pong et al. (1991).

\subsubsection{Sensory evaluation}

Eight well trained panelists of the research staff members of Food Technology Research Institute (FTRI, Giza, Egypt) judged the muffins for cells, grain, texture, crumb color, flavor and overall acceptability. A 9-point hedonic scale was used to 


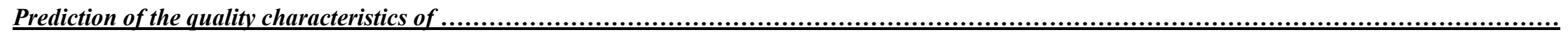

Table (1): Formulation of gluten-free corn muffins containing soy bean flour and xanthan gum.

\begin{tabular}{|c|c|c|c|c|c|c|c|c|c|c|}
\hline $\begin{array}{c}\text { Muffin } \\
\text { Code }\end{array}$ & $\begin{array}{c}\text { Corn } \\
\text { Flour }(g)\end{array}$ & $\begin{array}{l}\text { Soy bean } \\
\text { flour (g) }\end{array}$ & $\begin{array}{c}\text { Hot } \\
\text { Water } \\
(\mathrm{ml})\end{array}$ & $\begin{array}{c}\text { Cold } \\
\text { water } \\
(\mathrm{ml})\end{array}$ & Egg (g) & $\begin{array}{c}\text { Butter } \\
\text { (g) }\end{array}$ & $\begin{array}{c}\text { Sugar } \\
\text { (g) }\end{array}$ & $\begin{array}{r}\text { Salt } \\
\text { (g) }\end{array}$ & $\begin{array}{c}\text { Baking } \\
\text { Powder } \\
\text { (g) }\end{array}$ & $\begin{array}{c}\text { Xanthan } \\
\text { gum } \\
\text { (g) }\end{array}$ \\
\hline Control & 100 & 0 & 85 & 30 & 40 & 40 & 30 & 0.6 & 3.5 & 0 \\
\hline 1 & 90 & 10 & 85 & 30 & 40 & 40 & 30 & 0.6 & 3.5 & 0.3 \\
\hline 2 & 90 & 10 & 85 & 30 & 40 & 40 & 30 & 0.6 & 3.5 & 0.6 \\
\hline 3 & 90 & 10 & 85 & 30 & 40 & 40 & 30 & 0.6 & 3.5 & 1 \\
\hline 4 & 80 & 20 & 85 & 30 & 40 & 40 & 30 & 0.6 & 3.5 & 0.3 \\
\hline 5 & 80 & 20 & 85 & 30 & 40 & 40 & 30 & 0.6 & 3.5 & 0.6 \\
\hline 6 & 80 & 20 & 85 & 30 & 40 & 40 & 30 & 0.6 & 3.5 & 1 \\
\hline 7 & 70 & 30 & 85 & 30 & 40 & 40 & 30 & 0.6 & 3.5 & 0.3 \\
\hline 8 & 70 & 30 & 85 & 30 & 40 & 40 & 30 & 0.6 & 3.5 & 0.6 \\
\hline 9 & 70 & 30 & 85 & 30 & 40 & 40 & 30 & 0.6 & 3.5 & 1 \\
\hline 10 & 60 & 40 & 85 & 30 & 40 & 40 & 30 & 0.6 & 3.5 & 0.3 \\
\hline 11 & 60 & 40 & 85 & 30 & 40 & 40 & 30 & 0.6 & 3.5 & 0.6 \\
\hline 12 & 60 & 40 & 85 & 30 & 40 & 40 & 30 & 0.6 & 3.5 & 1 \\
\hline
\end{tabular}


rate the sensory properties as described by Watts et al. (1989). The 9-point choices on the hedonic scale were: extremely like, very much like, moderately like, slightly like, neither like nor dislike, slightly dislike, moderately dislike, very much dislike and extremely dislike. Every panelist was asked to test and check how much did (he or she) like the characteristics under test and also to show their attitude by checking the point that best described their feeling about the characteristic. After that, their ratings were given numerical values ranging from 9 (for extremely like) to 1 (for extremely dislike).

\subsubsection{Statistical analysis}

A randomized complete block design was used. Data obtained from chemical analysis, physical measurements and sensory evaluation of muffins were analyzed by Analysis of Variance using General Linear Model (GLM) procedure within a package program of Statistical Analysis System (SAS, 1999). Means were separated using Duncan's test at a degree of significance $(\mathrm{P} \leq 0.05)$. Models and prediction equations for the effects of independent variables used in this study (i.e. soybean flour $\%$ and xanthan gum,g) on the quality characteristics of gluten-free corn muffins were derived using Design-Expert7 ${ }^{\circledR}$ Software (Stat-Ease Corporation, Minneapolis, MN., USA).

\section{RESULTS AND DISCUSSION 3.1. Effect of soybean flour and xanthan gum on the gross chemical composition of gluten-free corn muffins}

The effect of adding soybean flour at different levels (i.e. 0, 10, 20,30, and 40\% of corn flour by weight) and xanthan gum (at levels of 0.3, 0.6 and $1 \mathrm{~g})$ on the chemical composition of gluten-free corn muffins is shown in Table (2). The results indicated that incorporation of soybean flour had a significant effect on most chemical constituents of the resultant gluten-free muffins. Muffins containing soybean flour had higher contents of moisture, protein, ash, dietary fiber. The increase in moisture content could be attributed to the increase in fiber content associated with the addition of soybean flour (Alam et al., 2013) while the increase in protein, fiber and ash contents is a result of the higher contents of such constituents in soybean flour when compared to corn flour (Soliman et al., 2009). On the other hand, this addition resulted in relatively lower contents of fats determined as ether extract. The protein content of gluten-free corn muffins with higher soybean flour levels was increased as up to twice as the control muffins. Moreover, dietary fiber contents of gluten-free corn muffins containing $40 \%$ soybean flour was increased by up to 4 times when compared to the control muffins. Ether extract decreased by $6.3 \%$ of the initial ether extract content. Digestible carbohydrates contents, calculated by difference, were changed by their turn as a result of the changes in other chemical constituents. The high increases in both protein and dietary fiber led to a significant decrease in digestible carbohydrate content of muffins containing soybean flour. Different studies found that enrichment of bakery products with defatted soybean flour improves the nutritional quality of bakery products with regard to the increase in high nutritional value protein and dietary fiber in particular (Dhingra and Jood , 2001, Bunde et al., 2010 and Man et al., 2014).

The addition of xanthan gum at levels of 0.3, 0.6 and $1 \mathrm{~g}$ had no major effect on the chemical composition of gluten-free muffins with the exception of a slight increase in the moisture content of muffins containing 0.6 and $1 \mathrm{~g}$ of xanthan gum for 30 and $40 \%$ soybean flour addition levels, respectively. This slight increase in moisture content was previously reported by Rosell et al. (2001) to be a result of the high capacity of the hydrocolloids to retain water. Hojjatoleslami and Azizi (2015) reported that cakes containing xanthan gum at levels of 0.5 and $1 \%$ had significantly higher moisture contents than the control ones $(23.07,24.21$ and $21.85 \%$, respectively). Moreover, the increase in moisture content can be attributed to the incorporation of soybean flour with higher fiber content than wheat flour (Alam et al., 2013)

\subsection{Effect of soybean flour and xanthan gum on the physical properties of gluten-free corn muffins}

Results in Table (3) show the effect of soybean flour and xanthan gum on the physical properties of gluten-free corn muffins. For batter density, it is clearly obvious that muffins containing soybean flour and xanthan gum had higher batter density values compared to the control ones. The increase in batter density can be attributed to the decrease in air volume incorporated to the batter as a result of adding 
Table (2): Gross chemical composition of gluten-free corn muffins as affected by the addition of soy bean flour and xanthan gum at different levels*.

\begin{tabular}{|c|c|c|c|c|c|c|c|c|}
\hline \multirow[t]{2}{*}{ Muffin Code } & \multirow{2}{*}{$\begin{array}{c}\text { Soy bean flour } \\
(\%)\end{array}$} & \multirow{2}{*}{$\begin{array}{c}\text { Xanthan gum } \\
\text { (g) }\end{array}$} & \multirow[t]{2}{*}{ Moisture } & Protein & Ether extract & Ash & Dietary fiber & $\begin{array}{c}\text { Digestible } \\
\text { carbohydrates }\end{array}$ \\
\hline & & & & \multicolumn{5}{|c|}{ (\% On dry weight basis) } \\
\hline Control & 0 & 0 & $25.3^{f}$ & $9.2^{i}$ & $25.5^{\mathrm{a}}$ & $4.8^{\mathrm{e}}$ & $1.0^{f}$ & $59.5^{\mathrm{a}}$ \\
\hline 1 & 10 & 0.3 & $27.2^{\mathrm{e}}$ & $10.8^{h}$ & $25.7^{\mathrm{a}}$ & $5.1^{\mathrm{cd}}$ & $1.8^{\mathrm{e}}$ & $56.6^{\mathrm{b}}$ \\
\hline 2 & 10 & 0.6 & $27.3^{\mathrm{e}}$ & $11.0^{\mathrm{h}}$ & $25.5^{\mathrm{a}}$ & $5.1^{\mathrm{cd}}$ & $1.8^{\mathrm{e}}$ & $56.6^{b}$ \\
\hline 3 & 10 & 1 & $27.2^{\mathrm{cd}}$ & $10.9^{\mathrm{g}}$ & $25.6^{\mathrm{a}}$ & $5.0^{\mathrm{de}}$ & $1.9^{\mathrm{e}}$ & $56.6^{b}$ \\
\hline 4 & 20 & 0.3 & $27.9^{\mathrm{de}}$ & $13.1^{\mathrm{f}}$ & $25.1^{\mathrm{ab}}$ & $5.1^{\mathrm{cd}}$ & $2.6^{\mathrm{d}}$ & $54.1^{c}$ \\
\hline 5 & 20 & 0.6 & $27.9^{\mathrm{de}}$ & $13.8^{\mathrm{fg}}$ & $24.9^{a b c}$ & $5.2^{\mathrm{cd}}$ & $2.7^{\mathrm{d}}$ & $53.4^{\mathrm{c}}$ \\
\hline 6 & 20 & 1 & $28.1^{\mathrm{de}}$ & $13.2^{\mathrm{e}}$ & $24.7^{\mathrm{abc}}$ & $5.3^{b c}$ & $2.9^{\mathrm{cd}}$ & $53.9^{c}$ \\
\hline 7 & 30 & 0.3 & $28.1^{\text {de }}$ & $16.0^{\mathrm{a}}$ & $24.0^{c}$ & $5.3^{b c}$ & $3.1^{\mathrm{c}}$ & $51.6^{\mathrm{d}}$ \\
\hline 8 & 30 & 0.6 & $30.9^{b}$ & $16.7^{d}$ & $24.9^{\mathrm{ab}}$ & $5.3^{b c}$ & $3.2^{b c}$ & $49.9^{\mathrm{e}}$ \\
\hline 9 & 30 & 1 & $31.9^{a}$ & $16.8^{d}$ & $24.8^{a b c}$ & $5.4^{\mathrm{ab}}$ & $3.4^{b}$ & $49.6^{\mathrm{e}}$ \\
\hline 10 & 40 & 0.3 & $29.0^{c}$ & $17.6^{\mathrm{c}}$ & $24.8^{a b c}$ & $5.7^{\mathrm{a}}$ & $4.1^{\mathrm{a}}$ & $47.8^{f}$ \\
\hline 11 & 40 & 0.6 & $31.0^{b}$ & $18.1^{b c}$ & $23.9^{c}$ & $5.6^{\mathrm{a}}$ & $4.1^{\mathrm{a}}$ & $48.3^{\text {ef }}$ \\
\hline 12 & 40 & 1 & $30.7^{b}$ & $18.8^{b}$ & $24.3^{b c}$ & $5.6^{\mathrm{a}}$ & $4.2^{\mathrm{a}}$ & $47.1^{\mathrm{f}}$ \\
\hline
\end{tabular}

* Means within the same column with the same letter $(\mathrm{s})$ are not significantly different $(\mathrm{P}<0.05)$

Table (3): Physical properties of gluten-free corn muffins as affected by the addition of soy bean flour and xanthan gum at different levels*.

\begin{tabular}{|c|c|c|c|c|c|c|c|}
\hline $\begin{array}{c}\text { Muffin } \\
\text { Code }\end{array}$ & $\begin{array}{l}\text { Soy bean } \\
\text { flour }(\%) \\
\end{array}$ & $\begin{array}{c}\text { Xanthan } \\
\operatorname{gum}(\mathrm{g})\end{array}$ & $\begin{array}{c}\text { Batter density } \\
\left(\mathrm{g} / \mathrm{cm}^{3}\right)\end{array}$ & $\begin{array}{c}\text { Weight } \\
\text { (g) }\end{array}$ & $\begin{array}{c}\text { Volume } \\
\left(\mathrm{cm}^{3}\right)\end{array}$ & $\begin{array}{l}\text { Height } \\
(\mathrm{mm})\end{array}$ & $\begin{array}{c}\text { Specific volume } \\
\left(\mathrm{cm}^{3} / \mathrm{g}\right)\end{array}$ \\
\hline Control & 0 & 0 & $1.07^{\mathrm{f}}$ & $17.2^{\mathrm{cd}}$ & $28.7^{\mathrm{de}}$ & $25.0^{\mathrm{f}}$ & $1.67^{\mathrm{c}}$ \\
\hline 1 & 10 & 0.3 & $1.13^{\text {ef }}$ & $17.2^{\mathrm{cd}}$ & $28.0^{\mathrm{de}}$ & $25.4^{\text {ef }}$ & $1.63^{c}$ \\
\hline 2 & 10 & 0.6 & $1.18^{\mathrm{de}}$ & $17.1^{\mathrm{cd}}$ & $31.3^{\mathrm{cd}}$ & $25.4^{\text {ef }}$ & $1.83^{a b c}$ \\
\hline 3 & 10 & 1 & $1.23^{\mathrm{cd}}$ & $19.3^{\mathrm{a}}$ & $34.0^{\mathrm{abc}}$ & $28.1^{\mathrm{a}}$ & $1.76^{\mathrm{abc}}$ \\
\hline 4 & 20 & 0.3 & $1.23^{\mathrm{cd}}$ & $17.1^{\mathrm{cd}}$ & $32.0^{\text {bcd }}$ & $25.8^{\mathrm{de}}$ & $1.87^{\mathrm{abc}}$ \\
\hline 5 & 20 & 0.6 & $1.30^{\mathrm{bc}}$ & $18.2^{\mathrm{abc}}$ & $30.0^{\text {cde }}$ & $26.2^{\mathrm{cd}}$ & $1.65^{c}$ \\
\hline 6 & 20 & 1 & $1.36^{\mathrm{b}}$ & $18.2^{a b c}$ & $37.0^{\mathrm{a}}$ & $28.6^{\mathrm{a}}$ & $2.03^{\mathrm{a}}$ \\
\hline 7 & 30 & 0.3 & $1.24^{\mathrm{cd}}$ & $17.6^{\mathrm{bc}}$ & $31.7^{\mathrm{cd}}$ & $25.5^{\text {def }}$ & $1.80^{a b c}$ \\
\hline 8 & 30 & 0.6 & $1.38^{b}$ & $17.0^{\mathrm{cd}}$ & $29.0^{\mathrm{de}}$ & $26.8^{b c}$ & $1.71^{b c}$ \\
\hline 9 & 30 & 1 & $1.50^{\mathrm{a}}$ & $18.7^{\mathrm{ab}}$ & $36.0^{\mathrm{ab}}$ & $26.8^{b c}$ & $1.93^{\mathrm{abc}}$ \\
\hline 10 & 40 & 0.3 & $1.35^{b}$ & $15.9^{\mathrm{e}}$ & $26.3^{\mathrm{e}}$ & $25.5^{\mathrm{ef}}$ & $1.65^{c}$ \\
\hline 11 & 40 & 0.6 & $1.50^{\mathrm{a}}$ & $16.9^{\mathrm{cd}}$ & $31.3^{\mathrm{cd}}$ & $25.5^{\text {def }}$ & $1.85^{a b c}$ \\
\hline 12 & 40 & 1 & $1.56^{\mathrm{a}}$ & $18.2^{\mathrm{a}}$ & $36.7^{\mathrm{a}}$ & $27.1^{b}$ & $2.02^{\mathrm{ab}}$ \\
\hline
\end{tabular}

* Means within the same column with the same letter(s) are not significantly different $(\mathrm{P}<0.05)$ 
xanthan gum as previously described by Gómez et al., (2007). This fact could be also explained by the increase in viscosity caused by the presence of hydrocolloids. High viscosity will obstruct air incorporation during mixing since shaking power and time were exactly the same (Miller and Hoseney, 1993 and Gómez et al., 2007). For muffin weight, small differences (but significant) were observed between the control muffins and those containing soybean flour and xanthan gum with a small standard deviation value (less than 1 g). Muffins containing higher xanthan gum level $(1 \mathrm{~g})$ tended to have relatively significant higher weights compared to other muffins. Concerning volume and height, it was noticed that muffins containing soybean flour and xanthan gum showed the highest volume and height values. A positive correlation was observed between xanthan gum addition level and muffin volume. These results coincided with those obtained by Gómez et al. (2007) who reported that xanthan cakes had the highest volume, with an increase of $12.3 \%$ over the control value compared to other hydrocolloids. Another study (Tubari et al., 2008) showed that addition of xanthan gum improved the rice cake volume more than the other hydrocolloids (i.e. guar, locust, k-carrageenan, HPMC, xanthan+guar and xanthan+carrageenan). On the other hand, a positive relationship was found between the addition level of xanthan gum and the specific volume of the resultant gluten-free corn muffins. Muffins containing $1 \%$ xanthan gum have achieved an increase of up to $21.6 \%$ over the specific volume of the control muffins. Previous studies showed that cakes formulated with xanthan gum demonstrated the highest specific volumes which can be attributed to the increase in batter viscosity associated with the addition of xanthan gum (Gómez et al.,2007, Tubari et al., 2008 and Preichardt et al., 2011). They reported that the high batter viscosity slows down the rate of $\mathrm{CO}_{2}$ diffusion and, consequently, allowed for improving the $\mathrm{CO}_{2}$ retention during the early stage of baking.

\subsection{Effect of soybean flour and xanthan gum on the sensory characteristics of gluten-free corn muffins}

The results presented in Table (4) showed the average values of hedonic sensory evaluation of the gluten-free corn muffins as affected by the addition of soybean flour and xanthan gum at different levels. Cells and texture properties of muffins were not significantly affected by the replacement of corn flour with soybean flour at $10 \%$ level and with the addition of up to $1 \mathrm{~g}$ of xanthan gum with a corresponding (very much like) rating . Corn flour muffin samples replaced by 20 up to $40 \%$ of soybean flour, and contained 1 $\mathrm{g}$ of xanthan produced muffins that were also not significantly different than the control muffins with regard to cells and texture sensory characteristics. Replacement of 20 up to $40 \%$ of corn flour with soybean flour with the addition of xanthan gum at different levels (i.e. 0.3, 0.6 or $1 \%)$ resulted in muffins with significantly lower for grain characteristic which were rated as (moderately like) and (slightly like) by the panelists. Concerning crumb color, it was significantly decreased with the addition of $20 \%$ or more of soybean flour. Addition of xanthan gum was found to have no significant effect on muffin crumb color. Regarding the flavor of gluten-free corn muffins, replacing up to $20 \%$ of corn flour by soybean flour did not have any adverse effect on muffins' flavor. At a replacement level of $30 \%$, panelists started to detect a "beany" flavor of soybean , which turned to be "near-undesirable" flavor by two panelists at $40 \%$ replacement level. With regard to the overall acceptability of glutenfree corn muffins, it could be stated that replacing up to $20 \%$ of corn flour by soybean flour in the presence of xanthan gum resulted in acceptable muffins by the panelists which were not significantly different than the control muffins. At 30 and $40 \%$ corn flour replacement levels with soybean flour, muffins scored a significantly lower overall acceptability scores but were still acceptable to the panelists. Padhi et al. (2015) found that muffins made from soy flour, that were daily consumed for 6 weeks were rated between "slightly like" and "moderately like". Therefore it was suggested that soy flour muffins are acceptable by consumers and such acceptability can be enhanced as well as revealed health messages delivered through a health claim.

3.4. Prediction of the effect of addition of soybean flour and xanthan gum on the gross chemical composition of gluten-free corn muffins

Prediction equations for the effect of addition of soybean flour and xanthan gum on the gross chemical composition of gluten-free corn muffins 
Table (4): Sensory characteristics of gluten-free corn muffins as affected by the addition of soy bean flour and xanthan gum at different levels *.

\begin{tabular}{|c|c|c|c|c|c|c|c|c|}
\hline Muffin Code & $\begin{array}{c}\text { Soy bean } \\
\text { flour } \\
(\%)\end{array}$ & $\begin{array}{c}\text { Xanthan gum } \\
\text { (g) }\end{array}$ & $\begin{array}{c}\text { Cells } \\
(9)\end{array}$ & $\begin{array}{l}\text { Grain } \\
\text { (9) }\end{array}$ & $\begin{array}{l}\text { Texture } \\
\text { (9) }\end{array}$ & $\begin{array}{c}\text { Crumb color } \\
(9)\end{array}$ & $\begin{array}{c}\text { Flavor } \\
\text { (9) }\end{array}$ & $\begin{array}{c}\text { Overall } \\
\text { acceptability } \\
(9)\end{array}$ \\
\hline Control & 0 & 0 & $8.6^{\mathrm{a}}$ & $8.8^{a}$ & $8.6^{\mathrm{a}}$ & $8.6^{\mathrm{a}}$ & $8.7^{\mathrm{a}}$ & $8.6^{\mathrm{a}}$ \\
\hline 1 & 10 & 0.3 & $7.9^{a b c}$ & $7.8^{a b}$ & $7.9^{\mathrm{ab}}$ & $7.7^{a b}$ & $8.0^{a b}$ & $7.8^{a b c}$ \\
\hline 2 & 10 & 0.6 & $7.6^{\mathrm{abcd}}$ & $7.6^{b c}$ & $7.5^{\mathrm{abcd}}$ & $7.8^{\text {abcd }}$ & $8.0^{a b}$ & $7.6^{\mathrm{abc}}$ \\
\hline 3 & 10 & 1 & $8.3^{a b}$ & $7.8^{a b}$ & $7.9^{\mathrm{ab}}$ & $7.7^{\mathrm{ab}}$ & $7.9^{\mathrm{ab}}$ & $8.3^{\mathrm{ab}}$ \\
\hline 4 & 20 & 0.3 & $7.4^{\mathrm{abcd}}$ & $6.3^{d}$ & $7.3^{\mathrm{bcd}}$ & $7.3^{a b c}$ & $7.6^{a b c}$ & $7.8^{a b c}$ \\
\hline 5 & 20 & 0.6 & $7.0^{\text {cde }}$ & $6.9^{\mathrm{bcd}}$ & $7.2^{\mathrm{bcd}}$ & $7.2^{b c}$ & $7.6^{\mathrm{abc}}$ & $7.6^{\mathrm{abc}}$ \\
\hline 6 & 20 & 1 & $7.4^{\mathrm{abcd}}$ & $7.2^{\mathrm{bcd}}$ & $7.7^{\mathrm{abc}}$ & $7.6^{a b}$ & $7.4^{\mathrm{abc}}$ & $7.8^{a b c}$ \\
\hline 7 & 30 & 0.3 & $6.4^{\mathrm{de}}$ & $6.7^{\mathrm{bcd}}$ & $6.4^{\mathrm{d}}$ & $6.8^{b c}$ & $7.4^{\mathrm{abc}}$ & $7.1^{b c}$ \\
\hline 8 & 30 & 0.6 & $6.4^{\mathrm{de}}$ & $6.6^{\mathrm{cd}}$ & $6.6^{\mathrm{cd}}$ & $6.6^{b c}$ & $6.6^{b c}$ & $6.6^{c}$ \\
\hline 9 & 30 & 1 & $7.4^{\mathrm{abcd}}$ & $7.0^{\mathrm{bcd}}$ & $7.6^{\mathrm{abc}}$ & $7.1^{b c}$ & $6.7^{b c}$ & $6.9^{b c}$ \\
\hline 10 & 40 & 0.3 & $6.0^{\mathrm{e}}$ & $6.5^{\mathrm{cd}}$ & $6.8^{\mathrm{bcd}}$ & $6.1^{\mathrm{c}}$ & $6.2^{c}$ & $6.8^{b c}$ \\
\hline 11 & 40 & 0.6 & $6.4^{\mathrm{de}}$ & $6.3^{\mathrm{d}}$ & $6.9^{\mathrm{abcd}}$ & $6.0^{\mathrm{c}}$ & $6.4^{\mathrm{c}}$ & $6.9^{b c}$ \\
\hline 12 & 40 & 1 & $7.1^{\text {bcde }}$ & $6.7^{\mathrm{bcd}}$ & $7.8^{\mathrm{ab}}$ & $6.7^{b c}$ & $6.3^{c}$ & $7.3^{b c}$ \\
\hline
\end{tabular}

* Means within the same column with the same letter(s) are not significantly different $(\mathrm{P}<0.05)$ 
are shown in Table (5). The results indicated that the changes in all chemical constituents of glutenfree corn muffins containing soybean flour and xanthan gum followed linear prediction equations. This gives an evidence to the single and independent effect of the study variables (Soybean flour \% and Xannthan gum g) on the chemical composition of the resultant gluten-free muffins. For moisture, protein, ash and dietary fiber, it was found that muffin's contents of such four constituents were positively related with the independent variables of the study (i.e. soybean flour \% and xanthan gum $g$ ) while ether extract was slightly negatively related to the soybean flour $\%$ variable. Digestible carbohydrates were decreased by the addition of both soybean flour and xanthan gum. $\mathrm{R}^{2}$ (coefficient of determination) indicates the proportion of the variance in the dependent variables (i.e. moisture, protein, ether extract, ash, dietary fiber and digestible carbohydrates) that is predictable from the independent variables (soybean flour $\%$ and xanthan gum g). All dependent variables have $\mathrm{R}^{2}$ values of about 0.7 up to 0.99 which means that the fit explains from 70 up to $99 \%$ of the total variation in the data about the average. Adequate precision is a measure of the contrast in predicted response relative to its associated error (a signal to noise ratio). All the prediction equations had values of adequate precision of more than 4 (8.69 and above) which reflects an adequate signal and suggests that the prediction equations best fits the data (Saravanan et al., 2012).

\subsection{Prediction of the effect of addition of soybean flour and xanthan gum on the physical properties of gluten-free corn muffins}

The obtained results (Table 6) showed the prediction equations which describes the changes in physical properties (i.e. batter density, weight, volume, height, and specific volume) of glutenfree corn muffins. Weight, volume, height and specific volume predicted equations were found to be of the first order (linear) while the equations for batter density were found to be of two factorial interaction order. The prediction equation for batter density reflects the importance of the effect of the interaction between the independent variables (i.e. soybean flour $\%$ and xanthan gum g). Volume and height of the produced gluten-free corn muffins were found to be positively correlated with xanthan gum addition level. The lower values of $\mathrm{R}^{2}$ of the prediction equations of specific volume indicated that the model explains only $18 \%$ of the variability of the response data around its mean. The primary effect of hydrocolloids in the muffins was to maintain the higher batter viscosity during heating. Higher viscosity values reduce gas diffusion and migration of the air cells as well as protect the batter from shocks or vibrations which may cause the emulsion to rupture resulting in a bakery product of low volume (Stewart, 1997). Khouryieh et al. (2005) stated that the texture of muffins containing xanthan gum were significantly firmer and chewier than the control ones.

\subsection{Prediction of the effect of addition of soybean flour and xanthan gum on the sensory characteristics of gluten-free corn muffins}

From the data shown in Table (7), it could be observed that the prediction equations which were derived to explain the changes in sensory characteristics (i.e. cells, grain, texture, crumb color, flavor and overall acceptability) as affected by the addition of soybean flour and xanthan gum, were of different orders according to the sensory characteristic under investigation. Cells, texture and crumb color were found to be under prediction equation of a type of "two factorial interaction" which shows the importance of the interaction between the independent variables (i.e. soybean flour $\%$ and xanthan gum $g$ ) in determining the aforementioned three sensory characteristics of the resultant gluten-free muffins. Additionally, flavor and overall acceptability were found to follow linear equations while the prediction equation for grain was of a quadratic type. Moreover, overall acceptability prediction equation indicated a slightly negative effect of soybean flour addition on the overall acceptability of gluten-free corn muffins, while the addition of xanthan gum had a positive and enhancing effect on such sensory characteristic. However, $\mathrm{R}^{2}$ values showed that 75 to up to $96 \%$ of the variance in the dependent variables (i.e. cells, grain, texture, crumb color, flavor and overall acceptability) are predictable from the independent variables (i.e. soybean flour $\%$ and xanthan gum g). Padhi et al., (2015) concluded that soy muffins containing relatively high proportion of soy flour (24\%) have achieved positive liking scores, and they suggested that 
Table (5): Prediction equations for the effect of addition of soy bean flour and xanthan gum on the gross chemical composition of gluten-free corn muffins *.

\begin{tabular}{|l|c|l|l|l|}
\hline \multicolumn{1}{|c|}{ Independent Variable } & Prediction equation & Process order & $\mathrm{R}^{2}$ & \multicolumn{1}{c|}{ Adequate precision } \\
\hline Moisture (\%) & $0.11 \mathrm{X}_{1}+1.81 \mathrm{X}_{2}+25.07$ & Linear & 0.790 & 13.30 \\
\hline Protein (\%) & $0.25 \mathrm{X}_{1}+0.27 \mathrm{X}_{2}+8.62$ & Linear & 0.896 & 17.30 \\
\hline Ether Extract (\%) & $-0.03 \mathrm{X}_{1}+0.08 \mathrm{X}_{2}+25.72$ & Linear & 0.694 & 8.69 \\
\hline Ash (\%) & $0.02 \mathrm{X}_{1}+0.05 \mathrm{X}_{2}+4.81$ & Linear & 0.920 & 20.52 \\
\hline Dietary fiber (\%) & $0.07 \mathrm{X}_{1}+0.27 \mathrm{X}_{2}+0.973$ & Linear & 0.990 & 60.93 \\
\hline Digestible Carbohydrates $(\%)$ & $-0.33 \mathrm{X}_{1}-1.04 \mathrm{X}_{2}+60.82$ & Linear & 0.918 & 20.28 \\
\hline
\end{tabular}

$*$ where $X_{1}=\%$ Soy bean flour and $X_{2}=g$ Xanthan gum

Table (6): Prediction equations for the effect of addition of soy bean flour and xanthan gum on the physical properties of gluten-free corn muffins*.

\begin{tabular}{|l|l|l|l|l|}
\hline \multicolumn{1}{|c|}{ Independent Variable } & \multicolumn{1}{c|}{ Prediction equation } & Process order & \multirow{2}{*}{$\mathbf{R}^{2}$} & \multirow{2}{*}{ Adequate precision } \\
\hline Batter Density $\left(\mathrm{g} / \mathrm{cm}^{3}\right)$ & $4.6 * 10^{-3} \mathrm{X}_{1}+0.06 \mathrm{X}_{2}+7.39 \mathrm{X}_{1} \mathrm{X}_{2}+1.06$ & 2FI & 0.974 & 34.68 \\
\hline Weight $(\mathrm{g})$ & $-0.03 \mathrm{X}_{1}+2.26 \mathrm{X}_{2}+16.97$ & Linear & 0.702 & 9.64 \\
\hline Volume $\left(\mathrm{cm}^{3}\right)$ & $0.08 \mathrm{X}_{1}+5.27 \mathrm{X}_{2}+27.49$ & Linear & 0.520 & 7.31 \\
\hline Height $(\mathrm{mm})$ & $-0.02 \mathrm{X}_{1}+2.99 \mathrm{X}_{2}+24.88$ & Linear & 0.744 & 9.49 \\
\hline Specific volume $\left(\mathrm{cm}^{3} / \mathrm{g}\right)$ & $2.73 * 10^{-3} \mathrm{X}_{1}+0.11 \mathrm{X}_{2}+1.68$ & Linear & 0.184 & 3.40 \\
\hline
\end{tabular}

$*$ where $\mathrm{X}_{1}=\%$ Soy bean flour and $\mathrm{X}_{2}=\mathrm{g}$ xanthan gum

Table (7): Prediction equations for the effect of addition of soy bean flour and xanthan gum on the sensory characteristics of gluten-free corn muffins*.

\begin{tabular}{|c|c|c|c|c|}
\hline Independent Variable & Prediction equation & Process order & $\mathrm{R}^{2}$ & Adequate precision \\
\hline Cells & $-0.08 X_{1}-0.46 X_{2}+0.06 X_{1} X_{2}+8.57$ & 2FI & 0.881 & 15.90 \\
\hline Grain & $\begin{array}{l}-0.12 \mathrm{X}_{1}-0.93 \mathrm{X}_{2}+1.37 \mathrm{X}_{1} \mathrm{X}_{2}+1.6 * 10^{-3} \mathrm{X}_{1}^{2}+1.07 \mathrm{X}_{2}^{2}+ \\
8.80\end{array}$ & Quadratic & 0.921 & 13.03 \\
\hline Texture & $-0.07 \mathrm{X}_{1}-0.84 \mathrm{X}_{2}+0.07 \mathrm{X}_{1} \mathrm{X}_{2}+8.48$ & 2FI & 0.796 & 12.34 \\
\hline Crumb color & $-0.07 \mathrm{X}_{1}-0.40 \mathrm{X}_{2}+0.03 \mathrm{X}_{1} \mathrm{X}_{2}+8.58$ & $2 \mathrm{FI}$ & 0.962 & 27.92 \\
\hline Flavor & $-0.06 X_{1}-0.29 X_{2}+8.74$ & Linear & 0.950 & 27.23 \\
\hline Overall acceptability & $-0.04 X_{1}+0.14 X_{2}+8.32$ & Linear & 0.746 & 9.86 \\
\hline
\end{tabular}

* where $\mathrm{X}_{1}=\%$ Soy bean flour and $\mathrm{X}_{2}=\mathrm{g}$ xanthan gum 
muffins might be a suitable functional food matrix for products made with soy flour.

For the optimization of the quality of muffins using the derived prediction equations, overall acceptability was used as a determinant factor. In order to perform the optimization process, soybean flour and xanthan gum levels were set within the Design-Expert7® Software to be within experimental range (0-40\%and 0-1g, respectively), and two liking scores were set to be the target of the optimization (very much like, moderately like) with corresponding numerical scores of 8 and 7. The optimized muffin formula for the achievement of very much like target was found to contain $11.05 \%$ and $0.99 \mathrm{~g}$ of soybean flour and xanthan gum, respectively. The corresponding values of such two ingredients to achieve the moderately like target were $34.88 \%$ and $0.64 \mathrm{~g}$, respectively.

\section{Conclusion}

The current study showed that gluten-free corn muffins are of improved nutritional value, good physical quality properties and high liking scores of the sensory characteristics based on hedonic scale method, can be produced by replacing up to $20 \%$ of corn flour by soybean flour and the addition of up to $1 \mathrm{~g}$ of xanthan gum . Different predictive equations were derived from the obtained data and were found to explain high proportion of the variability in the response data around its mean including chemical composition and nutritional value, physical properties and sensory characteristics of the resultant muffins with a reasonable adequate precision values. However, it was found that replacing up to $20 \%$ of corn flour with soybean flour in the presence of xanthan gum resulted in gluten-free form muffins which were comparable to control muffins.

\section{Acknowledgment}

We wish to thank Dr. Mahmoud A.M. Saleh, head researcher at the Food Technology Research Institute, Agricultural Research Center, for his comments on early versions of this manuscript.

\section{REFERENCES}

A.A.C.C. (2000). Approved Methods of the American Association of Cereal Chemists. Pub. by the American Association of Cereal Chemists, St. Paul, MNY, USA.

Abdel-Aal E.M. (2009). Functionality of starches and hydrocolloids in gluten-free foods. In:
Gluten-free food science and technology. Gallagher, E. (Ed.) Blackwell Publishing Ltd. UK. pp. 200-224.

Alam M. J., Talukder M.U., Rahman M.N, Prodhan U.K. and Huq A.K.O. (2013). Evaluation of the nutritional and sensory quality of functional breads prepared from whole wheat and soybean flour. Annals Food Sci. Tech., 14: 171-175

Backman S. (2008). Soy flour in baking. Milling J. 16: 38-40.

Barada K., Bitar A., Mokadem M.A., Hashah J.G. and Green P. (2010). Celiac disease in Middle Eastern and North African countries: A new burden? . World J. Gastroenterol., 16: 1449-1457.

Bunde M.C., Osundahunsi F.O. and Akinos R. (2010). Supplementation of biscuit using rice bran and soyabean flour, AJFAND, 10: 47-59.

Cataldo F. and Montalto G. (2007). Celiac disease in the developing countries: A new and challenging public health problem. World J. Gastroenterol., 13: 2153-2159.

Cureton P. and Fasano A. (2009). The increasing incidence of celiac disease and range of glutenfree products in the marketplace. In: Glutenfree food science and technology. Gallagher, E. (Ed.),Blackwell Publishing Ltd. UK. pp.1-15.

Dhingra S. and Jood S. (2001). Organoleptic and nutritional evaluation of wheat breads supplemented with soybean and barley flour. Food Chem., 77: 479-488.

García-Ochoa F., Santos V.E., Casas J.A. and Gómez E. (2000). Xanthan gum: production, recovery, and properties. Biotech. Adv., 18: 549-579.

Gómez M., Ronda F., Caballero P.A., Blanco C.A. and Rosell C.M. (2007). Functionality of different hydrocolloids on the quality and shelflife of yellow layer cakes. Food Hydr., 21: 167-173.

Greco L., Timpono L., Abkari A., Abu-Zikry M., Attard T., Bouguerrà F., Cullufi P., Kansu A., Micetic-Turk D., Mišak Z., Roma E., Shamir R. and Terzic S. (2011). Burden of celiac disease in the Mediterranean area. World J. Gastroenterol., 45: 4971-4978.

Hojjatoleslami M. and Azizi M. (2015). Impact of Tragacanth and Xanthan Gums on the Physical and Textural Characteristics of Gluten-free Cake. Nutr. Food Sci. Res., 2:29-37. 
Hoseney R.C. (1989). The interaction that produces unique products from wheat flour. In: Wheat Is Unique. Pomeranz, Y. (Ed.) Amer. Assoc. Cereal Chemists. St. Paul, MN., USA. pp. 595-606.

Khouryieh H. A., Aramouni F.M. and Herald T.J. (2005). Physical and sensory characteristics of no-sugar-added/ low-fat muffin. J. Food Quality, 28: $439-451$.

Köksel H. F. (2009). Effects of xanthan and guar gums on quality and staling of gluten-free cakes baked in microwave-infrared combination oven. M.Sc. thesis, Middle East Technical University. Ankara, Turkey.

Lai H.M. and Lin T.C. (2006). Bakery products: science and technology. In: Bakery products: science and technology, Hui, Y.H. (Ed.) Blackwell Publishing, UK. pp.3-65.

Man S., Păucean A., Muste S. and Pop A. (2014). Studies on the formulation and quality characteristics of gluten-free muffins. J. Agroalimentary Proc. Tech., 20: 122-127.

Martínez-Cervera S., Salvador A., Muguerza B., Moulay L. and Fiszman S. M. (2011). Cocoa fibre and its application as a fat replacer in chocolate muffins. LWT-Food Sci. and Tech.. 44: 729-736.

Miller R.A. and Hoseney R.C. (1993). The role of xanthan gum in white layer cake. Cereal Chem., 70: 585-588.

Padhi E.M.T., Ramdath D.D., Carson S.J., Hawke A., Blewett H.J., Wolever T.M.S., Vella D., Seetharaman K., Duizer L.M. and Duncan A.M. (2015). Liking of soy flour muffins over time and the impact of a health claim on willingness to consume. Food Res. Int'1, 77: 491-497.

Pong L., Johnson J.M., Barbeau W.E. and Stewart D.L. (1991). Evaluation of alternative fat and sweetener systems in cupcakes. Cereal Chem., 68: 552-555.

Preichardt L.D., Vendruscolo C.T., Gularte M.A. and Moreira A.D.S. (2011). The role of xanthan gum in the quality of gluten-free cakes: improved bakery products for celiac patients. Int, J. Food Sci. and Tech., 46: 25912597.

Renzetti S., Bello F. D. and Arndt E.K. (2008). Microstructure, fundamental rheology and baking characteristics of batters and breads from different gluten-free flours treated with a microbial transglutaminase. J. Cereal Sci., 48: 33-45.

Riaz M.N. (1999). Soybeans as functional foods. Cereal Foods World, 44: 88-92.

Rosell C.M., Rojas J.A. and Benedito de Barber C. (2001). Influence of hydrocolloids on dough rheology and bread quality. Food Hydrocol., 15: 75-81.

Sadler M . J. (2005). Soy and health 2004: clinical evidence, dietetic applications. Nutr. Bull., 30: 385-391.

SAS (1999). Statistical Analysis System. User's Guide: Statistics, SAS Institute INC., Cary, NC, USA.

Saravanan P., Muthuvelayudham R. and Viruthagiri T. (2012). Application of Statistical Design for the Production of Cellulase by Trichoderma reesei Using Mango Peel. Enzyme Research, 2012: 1-7.

Soliman S.A., Mahmoud M.H.M., Abd El-Latif B.M., Bahlol H.E. and Abou El-Azem H.A. (2009). Production of balady bread by using some improvers. Annals Agric. Sci. Moshtohor, 47: 181-197.

Stewart S. (1997). Effect of flaxseed gum on muffin and salad dressing quality and stability. M.Sc. thesis. University of Manitoba. Winnipeg, Canada.

Tubari E., Sammu G. and Sahin S. (2008). Rheological properties and quality of rice cakes formulated with different gums and an emulsifier blend. Food Hydro., 22: 305-312.

Venter C. (1999). Health benefits of soybean $s$ and soy products: A review. J. Family Ecol. consumer sci., 27: 24-33.

Watts B.M., Ylimaki G.L., Jeffery L.E. and Elias L.G. (1989). Basic sensory methods for food evaluation. Int 1 Develop. Res. Centre. Ottawa, Ontario, Canada. 
التنبؤ بخصائص جودة مافن الأرة الخالية من الجلوتين و تأثر ها

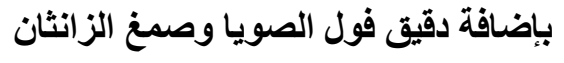

\section{مختار حرب عبد الخالق ـ أمانى محمد صقر - منال حجاج عبد القادر}

$$
\text { معهُ بحوث تكنولوجيا الأغذبة - مركز البحوث الزراعية - الجيزة - مصر }
$$

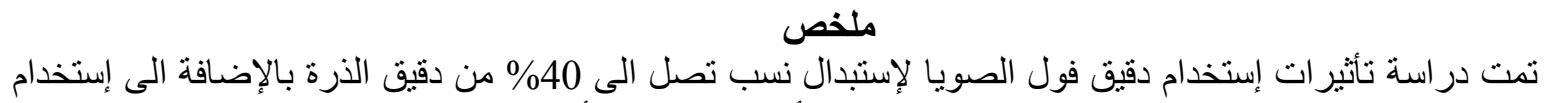

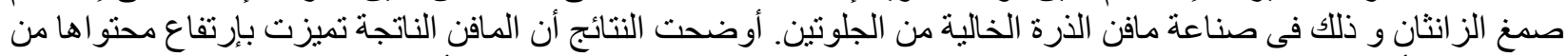

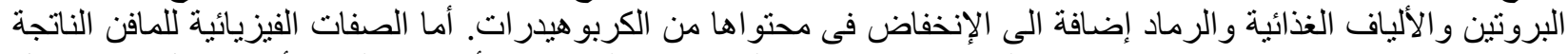

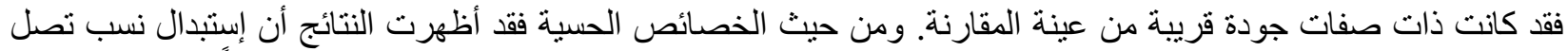

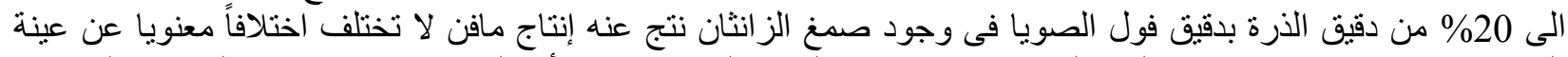

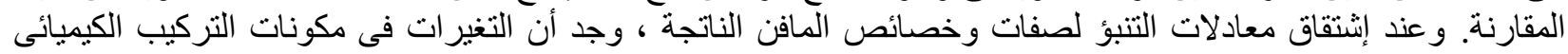

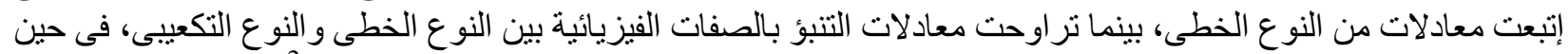

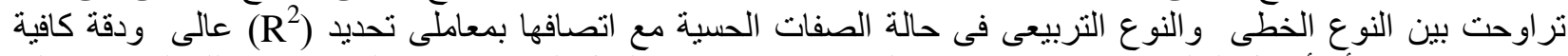

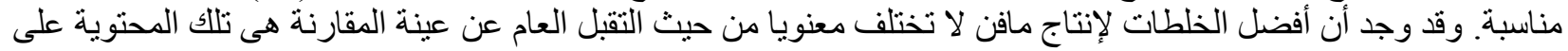

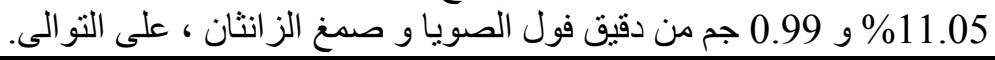

